\title{
Intrafollicular lipopolysaccharide injection delays ovulation in cows
}

\author{
Patrícia Gindri ${ }^{\mathrm{a}}$, Natália de Ávila Castro ${ }^{\mathrm{a}}$, Bruna Mion ${ }^{\mathrm{a}}$, Bernardo Garziera Gasperin ${ }^{\mathrm{a}}$, \\ Ligia Margareth Catarelli Pegoraro ${ }^{\mathrm{b}}$, Joao Alveiro Alvarado Rincón ${ }^{\mathrm{a}}$, \\ Arnaldo Diniz Vieira ${ }^{a}$, Jorgea Pradieéa, Luiz Francisco Machado Pfeifer ${ }^{c}$, \\ Marcio Nunes Corrêa ${ }^{\mathrm{a}}$, Augusto Schneider ${ }^{\mathrm{a}, *}$ \\ ${ }^{\text {a }}$ Universidade Federal de Pelotas, Pelotas, RS, Brazil \\ ${ }^{\mathrm{b}}$ Empresa Brasileira de Pesquisa Agropecuária (EMBRAPA) Clima Temperado, Pelotas, RS, Brazil \\ ${ }^{\mathrm{c}}$ Empresa Brasileira de Pesquisa Agropecuária (EMBRAPA), Porto Velho, RO, Brazil
}

\section{A R T I C L E I N F O}

\section{Keywords:}

Bovine

Inflammation

LPS

Ovary

\begin{abstract}
A B S T R A C T
The aim of this study was to evaluate effects of intra-follicular (i.f.) treatment with lipopolysaccharide (LPS) on follicular and luteal development in cows. There were 18 non-lactating cows assigned to two groups to address this aim: control group $(n=9)$, which received an i.f. injection of saline; and LPS group $(n=9)$, which received an i.f. injection of $1 \mu \mathrm{g}$ of LPS per $\mathrm{mL}$ of follicular fluid. Cows were treated with an intravaginal P4 releasing device (IVD) and estradiol benzoate on D0. On D4 and D5 cows were treated with cloprostenol sodium and on D7 the IVD was removed. At $12 \mathrm{~h}$ after IVD removal, cows were administered the i.f. injection of LPS or saline. After administration of these treatments, follicular development was evaluated every $12 \mathrm{~h}$ until ovulation. The LPS treatment increased blood flow in pre-ovulatory follicles $(P=0.05)$. Follicle growth was reduced by LPS injection $(P<0.02)$ resulting a longer period to the time of ovulation for cows in the LPS than control group $(P=0.03)$. The percentage of cows having ovulations was less for the LPS than control group $(P=0.03)$. The diameter of the CL, CL blood flow and P4 concentrations 5 and 12 days after ovulation did not differ between groups $(P>0.05)$. In conclusion, intra-follicular treatment with LPS resulted in a decreased rate of follicle growth, delayed timing of ovulations and a lesser number of cows having ovulations.
\end{abstract}

\section{Introduction}

In dairy cows, the non-lactating to lactating transition period is characterized by several physiological, nutritional, metabolic and immunological changes (Esposito et al., 2014). During this period there is a relatively greater energy demand for milk production, which that contributes to a lesser capacity of cows to ingest dry matter to meet energy requirements, and leads to a state of negative energy balance (NEB) (Bauman and Currie, 1980). As a result, during NEB, cows have a suppressed immune system function (Hammon et al., 2006) and become more susceptible to diseases such as metritis and endometritis (Lucy, 2008; Drackley and Cardoso, 2014). About 50\% of high producing dairy cows have at least one or more clinical disorders in the first 60 days after calving (Ribeiro et al., 2016). These diseases have been associated with reduced conception rates, longer calving to conception intervals

\footnotetext{
* Corresponding author at: Rua Gomes Carneiro, 1 Sala 239, CEP 96010-610, Pelotas, RS, Brazil.

E-mail address: augusto.schneider@ufpel.edu.br (A. Schneider).
} 
(CCI), and greater culling rates due to infertility (LeBlanc et al., 2002; Sheldon and Dobson, 2004; Sheldon et al., 2009).

The main infectious causative agent of diseases such as metritis, endometritis and mastitis are the gram-negative bacteria Escherichia coli (E. coli) (Sheldon et al., 2002). The external membrane of E. coli contains lipopolysaccharides (LPS), endotoxins that are inducers of the inflammatory response (Carroll et al., 2009; Bromfield and Sheldon, 2013). There have been suggestions that LPS can affect the hypothalamus and hypophysis inhibiting the release of gonadotropins, disrupting ovarian follicular growth (Suzuki et al., 2001; Williams et al., 2007). During infectious diseases LPS can be released into the circulation and transported to and have effects on tissues distant from the site of infection, such as in the ovarian follicles (Hakogi et al., 1989; Mateus et al., 2003; Herath et al., 2007; Magata et al., 2015). Directly and indirectly, therefore, uterine and mammary infections interfere with ovarian functions, reducing follicular growth and estradiol (E2) production, disrupting luteal function and resulting in impaired ovarian functions during the estrous cycle (Sheldon et al., 2002; Lavon et al., 2008).

Granulosa cells of the follicle express the toll-like receptor 4 (TLR4) gene (Herath et al., 2007; Magata et al., 2014), the main receptor through which LPS has actions (Moresco et al., 2011). Additionally, LPS can induce a TRL4 dependent inflammatory response in granulosa cells of the antral follicle in vitro (Bromfield and Sheldon, 2011). Similarly, in vivo intravenous injection of LPS modulates the expression of TLR4 and tumor necrosis factor $\alpha$ (TNF $\alpha$ ) and decreases the expression of steroidogenic genes in granulosa cells of the dominant follicle (Campos et al., 2017). These findings indicate follicular cells have the capacity to detect LPS and a local inflammatory response is initiated as a consequence that disrupts the steroidogenic process. These findings are consistent with results where $E$. coli infections or LPS infusion in vivo suppress E2 production and follicular growth in cattle (Battaglia et al., 2000; Sheldon et al., 2002). Cows with postpartum uterine lumen contamination have a slower growth rate of the first postpartum dominant follicle, lesser plasma concentrations of E2 and progesterone (P4), as well as a reduction in the percentage of cows having ovulations early in the postpartum period (Sheldon et al., 2002; Williams et al., 2007; Sheldon et al., 2009).

Interestingly, concentrations of LPS in the follicle correlates with the severity of the uterine disease (Herath et al., 2007). Cows diagnosed with metritis have greater concentrations of intra-follicular LPS compared to healthy control cows, and there were persistent effects in the transcriptome of granulosa cells even 6 weeks after resolution of uterine disease (Piersanti et al., 2019). Ovarian follicles of cows with endometritis have greater concentrations of LPS and lesser E2 concentrations (Magata et al., 2014). These findings indicate that besides a systemic effect, LPS may also have a local effect on ovarian follicles. Supporting this hypothesis, the secretion of E2 was less from granulosa cells of cattle in response to LPS during in vitro culture (Price et al., 2013). These results, therefore, indicate that LPS had marked effects on steroidogenesis. Because there can be LPS in the serum and follicular fluid (Herath et al., 2007; Magata et al., 2014), it is not possible to determine whether these effects occur at the systemic or directly at the ovarian follicle. The hypothesis for the present study, therefore, is that LPS has direct effects on ovarian follicular development. Furthermore, there was an aim to evaluate the effects of the intra-follicular (i.f.) injection of LPS on follicular and luteal development in cows.

\section{Materials and methods}

All procedures performed in this study were approved by the Ethics and Animal Experimentation Committee of the Universidade Federal de Pelotas, under protocol number 23110.048134/2018-05.

\subsection{Animals and experimental design}

For this experiment, 22 non-lactating Jersey (Bos taurus taurus) cows were used, with an average body condition score of $3.0 \pm 0.1$ (on a scale of 1-5), and the same management and feeding regimen was imposed on all cows. Cows allocated to the study had no signs of uterine or mammary infections. All cows were submitted to a hormonal protocol for inducing and synchronizing the time of ovulation (Fig. 1). On Day 0 (D0) of the treatment regimen, follicles with a diameter $\geq 8$ mm were aspirated and cows were treated with an intravaginal P4 releasing device (IVD, $1 \mathrm{~g}$, Primer ${ }^{\circledR}$ ) and an injection of $2 \mathrm{mg}$ of E2 benzoate (Sincrodiol ${ }^{\circledR}$ ) i.m. On D4 and D5 cows were administered an injection of $500 \mu \mathrm{g}$ cloprostenol sodium (Estron ${ }^{\circledR}$ ) i.m. After D5, cows were evaluated every $24 \mathrm{~h}$

US

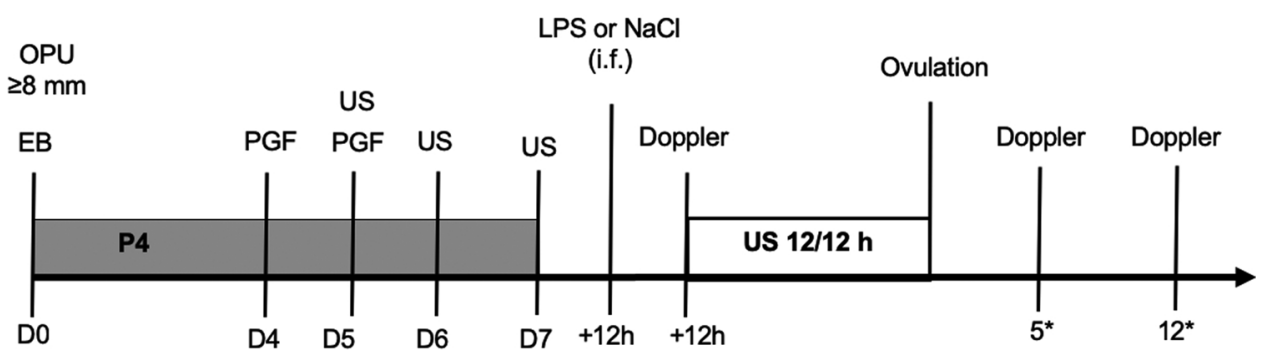

Fig. 1. Experimental design and hormonal protocol; Cows of LPS group $(n=9)$ were treated with an intrafollicular injection of lipopolysaccharide (LPS; $1 \mu \mathrm{g} / \mathrm{mL}$ ) and the control group $(n=9)$ were administered an intrafollicular injection of saline solution ( $\mathrm{NaCl} 0.9 \%), 12 \mathrm{~h}$ after withdrawal of an intravaginal progesterone device; P4: Progesterone; EB: Estradiol Benzoate; PGF: Prostaglandin F2 $\alpha$ (Cloprostenol sodium); US: Ultrasonography; *Days after ovulation. 
using trans-rectal ultrasonography to monitor follicle growth. On D7, the IVD was removed (Fig. 1). There were no significant amounts of pus observed at the time of IVD removal.

At $12 \mathrm{~h}$ (D8) after IVD removal, cows were examined using trans-rectal ultrasonography. Only cows that had follicles with diameter $\geq 8.8 \mathrm{~mm}$ remained in the experiment $(n=18)$. Thus, 18 animals were randomly assigned to two groups: LPS group that were administered an intrafollicular (i.f.) injection of LPS $(n=9)$ and control group $(n=9)$ that were administered an i.f. injection of saline solution ( $\mathrm{NaCl} 0.9 \%$ ). The rectal temperature of all cows was measured $12 \mathrm{~h}$ after the i.f. injection.

\subsection{Treatments and intrafollicular injection}

The LPS group that was treated with an i.f. injection of LPS from E. coli (O111:B4, Sigma-Aldrich, St. Louis, MO, USA). The amount of injected LPS was calculated to be $1 \mu \mathrm{g}$ of LPS per $\mathrm{mL}$ of follicular fluid (using $10 \mu \mathrm{g} / \mathrm{mL}$ of LPS solution), based on treatments in previous studies conducted with in vitro culture of granulosa cells and concentrations of LPS detected in the follicular fluid of cows with endometritis (Herath et al., 2007; Bromfield and Sheldon, 2011). The injected volume was calculated based on the volume of follicular fluid estimated using a regression equation, $V=-685.1+120 D$, where $V$ corresponds to the estimated follicular volume and $D$ the diameter of the follicle to be injected (Ferreira et al., 2007). In the LPS group the volume injected averaged $63.9 \pm 6.1 \mu \mathrm{L}$, while in the control group, the average volume of saline solution injected was $73.0 \pm 7.9 \mu \mathrm{L}$.

Prior to i.f. injections, epidural anesthesia was performed by injection of lidocaine chloride ( $2 \%)$, and the perianal and vulvar regions were sanitized. To conduct the i.f. injections, there was use of transvaginal ultrasonography (transvaginal transducer, $7.5 \mathrm{mHz}$ ) to assist in guiding the needle for making the injections as described by Ferreira et al. (2007) with some adaptations. Briefly, a system containing the probe and a $20 \mathrm{G}$ needle $(0.8 \mathrm{~mm}$ x $40 \mathrm{~mm}$; Becton, Dickinson and Company, USA) was used to puncture the vaginal wall, peritoneum and ovarian stroma until the needle was placed close the dominant follicle. For puncturing the follicle wall and injection an internal $25 \mathrm{G} 3$ 1/2 needle was used (BD, USA). For the injection a $0.3 \mathrm{~mL}$ insulin syringe was used, and the aspiration line was filled with the solution (LPS or Control) to allow the calculated volume to be transferred into the follicle after the needle was positioned inside the follicle. When a swirling motion of the solution entering the follicle was observed with use of ultrasonography, this was considered to indicate the injection was successful. After removal of the needle from inside the follicle there was an observation of follicle integrity with ultrasonic monitoring. Follicle diameter and position was recorded to allow for ease in identification of the follicle at the time of subsequent ultrasonic evaluations.

\subsection{Follicular growth, estrous detection and ovulation}

To evaluate growth of the injected follicle, transrectal ultrasonography was performed at intervals of $12 \mathrm{~h}$ from the time of injection until the time ovulation had been detected to have occurred. Ovulation was considered to have occurred when there was disappearance of the follicle that had been identified as the dominant follicle at the time of previous ultrasonic evaluations (Martinez et al., 2005). The diameter of the follicle from which ovulation occurred was considered to be the follicular diameter determined at the last visualization before the time ovulation was considered to have occurred. The time of ovulation was considered to have occurred $6 \mathrm{~h}$ after the last detection of the preovulatory follicle. For estrous detection, $24 \mathrm{~h}$ after i.f. injection there was placement of an estrous detector (Estrotect ${ }^{\circledR}$, Spring Valley, Wisconsin, USA) to identify signs of estrous activity each $12 \mathrm{~h}$ at the time when there were ultrasonic examinations. For cows in which ovulation was not detected to have occurred, there was continuation of assessments of follicle growth until $192 \mathrm{~h}$ after the time of the follicular injections (8 days).

\subsection{Follicular blood flow}

To verify the vascularization of the injected follicles, transrectal ultrasonography was conducting using color Doppler (M5 VET ${ }^{\circledR}$ ) $24 \mathrm{~h}$ after the i.f. injection. Follicle images were obtained from sonographic evaluations with maximum color intensity, focusing on the area where there was the greatest diameter of the follicle. When consistent Doppler readings were detected for blood flow in the follicular wall, the follicle was considered to have detectable blood flow. The intensity of follicular vascularization was subjectively expressed as the percentage of peripolar circumference that had indications of color Doppler, as described previously (Ginther, 2007). The follicles were classified using scores from 1 to 4 , where a grade 1 score was indicative of mild vascularization ( $\leq 25 \%$ ), grade 2 little to intermediate ( $>25$ and $\leq 50 \%$ ), grade 3 moderate ( $>50$ and $<75 \%$ ) and grade 4 greatest vascularization $(>75 \%)$. Scores were determined by a single person unaware of the sample grouping.

\subsection{Luteal blood flow}

For cows that had ovulations ( $n=9$ of the control group; $n=6$ for LPS group), there were ultrasonic evaluations 5 and 12 days after ovulation, for the measurement of the corpus luteum (CL) diameter and evaluation of luteal vascularization using color Doppler ultrasonography (M5 VET ${ }^{\circledR}$ ). Both of the ovaries of all animals were evaluated, and there was recording of the location of the CL of each animal. Short videos were then made, lasting $7 \mathrm{~s}$. The area of the CL was measured using the internal calibers of the instrument. In cases where the CL was cavitary, the area of CL and the area of the CL cavity were calculated and then the luteal tissue area (LTA) was by subtracting the area of the cavity. Regarding the quantitative evaluation of vascularization, there was an image obtained at the time there was a maximum CL diameter and there was analysis using the Image ${ }^{\circledR}$ software to determine the area of colored pixels within the CL. The evaluation of the CL blood flow (CLBF) was conducted indirectly, by means of a visual estimate. To obtain the 
adjusted CLBF the CLBF was divided by LTA (CLBF:LTA ratio), so that the proportion of colored pixels in relation to the area of the luteal tissue was determined. Scores were evaluated by a single person unaware of the sample grouping.

\subsection{Measurement of $P 4$}

On days five and 12 after ovulation ( $n=9$ for control group; $n=6$ for LPS group) blood samples were collected by puncturing the coccygeal vein in Vacutainer ${ }^{\circledR}$ tubes. Serum P4 was measured using the chemiluminescence method in a commercial laboratory (Laboratório Pasin, Santa Maria, RS, Brazil) (Campos et al., 2017).

\subsection{Statistical analysis}

Statistical analyses were performed using GraphPad ${ }^{\circledR} 6.01$ (GraphPad software, Inc., CA, USA) and SAS 9.0 (SAS Institute, Inc., Cary, NC, USA) software. Follicular diameter, rectal temperature, time of estrus, time of ovulation, diameter of dominant follicle at the time of ovulation P4, area of luteal tissue and blood flow of CL were evaluated using the Student's t-test Follicular growth was assessed using the mixed procedure in SAS, considering the effect of treatment, time and treatment by time interaction. When individual means were significant, these were compared using Tukey's post-hoc test. Blood flow was evaluated by Mann Whitney's test. The ovulatory rate was evaluated through chi-square anlaysis and also through survival curve analysis (Gehan-BreslowWilcoxon) for observing ovulatory rate along the period of evaluations occurred. Values of $P \leq 0.05$ were considered to be significant and the data are presented as a mean and SEM.

\section{Results}

Follicle diameter at the time of injection was not different between control $(10.9 \pm 0.6 \mathrm{~mm})$ and LPS groups $(10.6 \pm 0.6 \mathrm{~mm} ; P$ $=0.6$ ). Additionally, after the LPS treatment, rectal temperature did not change (control $37.4 \pm 0.2^{\circ} \mathrm{C}$ compared LPS $\left.37.6 \pm 0.1{ }^{\circ} \mathrm{C} ; P=0.7\right)$. Follicle blood flow score $24 \mathrm{~h}$ after the LPS treatment was greater $(2.4 \pm 0.2)$ than in control group $(1.6 \pm 0.2 ; P=0.05)$.

Follicle growth was less in the LPS group $(P<0.02$; Fig. 2). Consequently, in cows in the LPS group, there was a longer period from D0 to the time ovulations occurred $(106.0 \pm 13.0 \mathrm{~h})$ compared to control group $(78.0 \pm 4.9 \mathrm{~h} ; P=0.03)$. Cows in the control group had ovulations between 54 and $102 \mathrm{~h}$, while cows in the LPS group had ovulations between 78 and $162 \mathrm{~h}$ after the i.f. injection. Even though there was a delay in the time of ovulation, diameter of the dominant follicle at the time of ovulation was similar between groups (control $12.82 \pm 0.43 \mathrm{~mm}$ compared with LPS $11.60 \pm 0.69 \mathrm{~mm} ; P=0.1$ ). The percentage of cows having ovulations in the control group was $100 \%(9 / 9)$, while for LPS group it was $66.7 \%(6 / 9)(P=0.21)$. Results using the survival analysis indicated there was a lesser percentage of cows having ovulations in the LPS-treated than control group (Fig. $3, P=0.03$ ). For the cows in the LPS group that did not have ovulations, the follicles regressed in the week following the treatment with LPS. There tended to be a longer period from D0 to the time of estrous expression in cows of the LPS-treated than control group (control $54.9 \pm 6.9 \mathrm{~h}$ compared with LPS $74.4 \pm 5.9 \mathrm{~h} ; P=0.06)$.

For those cows that had ovulations ( $n=9$ for control and $n=6$ for LPS group) the diameter of the CL at D5 (control $19.0 \pm 0.6 \mathrm{~mm}$ compared with LPS $18.5 \pm 1.1 \mathrm{~mm} ; P=0.6$ ) and D12 (control $22.7 \pm 1.0 \mathrm{~mm}$ compared with LPS $22.1 \pm 1.0 ; P$ $=0.7$ ) was not different between groups. Also the area of luteal tissue at D5 (control $16.5 \pm 1.9 \mathrm{~mm}$ compared with LPS $15.1 \pm 1.6 \mathrm{~mm} ; P=0.5$ ) and D12 (control $18.4 \pm 1.3 \mathrm{~mm}$ compared with LPS $18.8 \pm 1.3 \mathrm{~mm} ; P=0.8$ ) was not different between

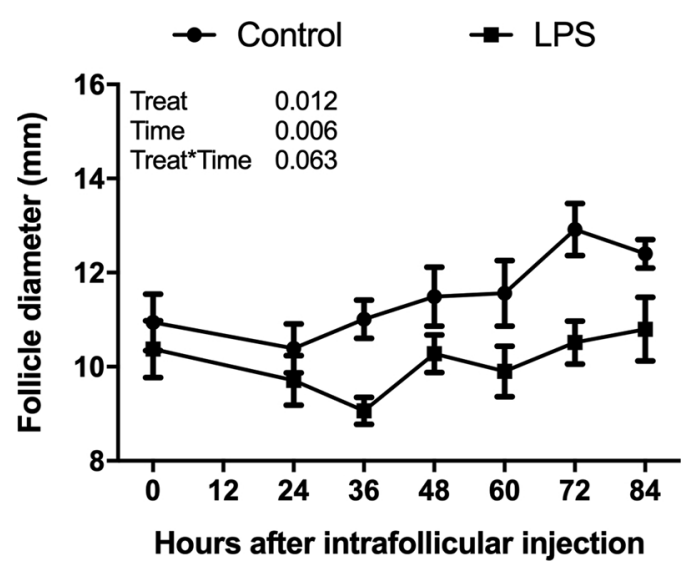

Fig. 2. Follicular diameter of cows from LPS and control groups after intrafollicular injections; Cows of the LPS group ( $n=9)$ were administered an intrafollicular injection of lippolysaccharide (LPS; $1 \mu \mathrm{g} / \mathrm{mL})$ and the control group $(n=9)$ were treated with an intrafollicular injection of saline solution $(\mathrm{NaCl} 0.9 \%) 12 \mathrm{~h}$ after withdrawal of an intravaginal progesterone device; Follicular growth was evaluated using the mixed procedure in the SAS software, considering the effect of treatment, time and treatment by time interaction; Values of $P \leq 0.05$ were considered significant. 


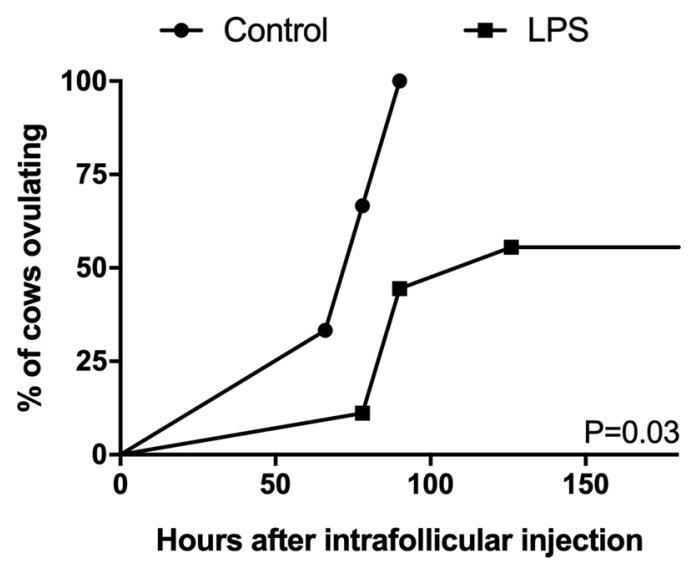

Fig. 3. Results from use of survival analysis of the ovulatory rate of cows from LPS and control groups; Cows of the LPS group ( $n=9$ ) were administered an intrafollicular injection of lipopolysaccharide (LPS; $1 \mu \mathrm{g} / \mathrm{mL})$ and the control group $(n=9)$ was treated with an intrafollicular injection of saline solution ( $\mathrm{NaCl} 0.9 \%) 12 \mathrm{~h}$ after withdrawal of an intravaginal progesterone device; The ovulatory rate was evaluated using survival curve analysis (Gehan-Breslow-Wilcoxon); Values of $P \leq 0.05$ were considered significant.

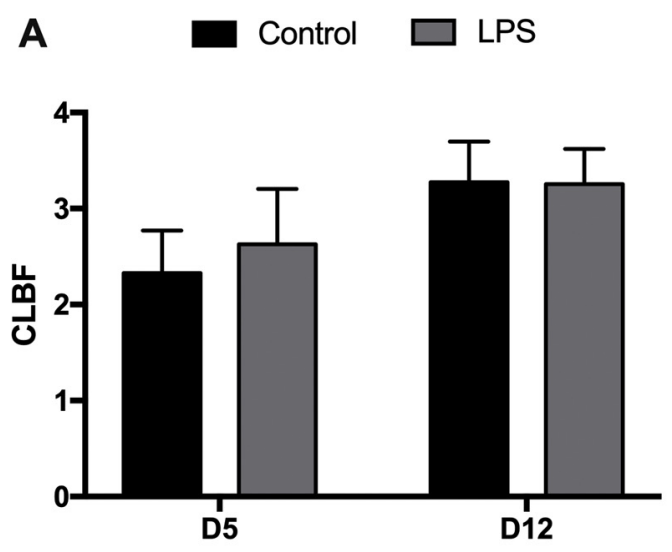

B

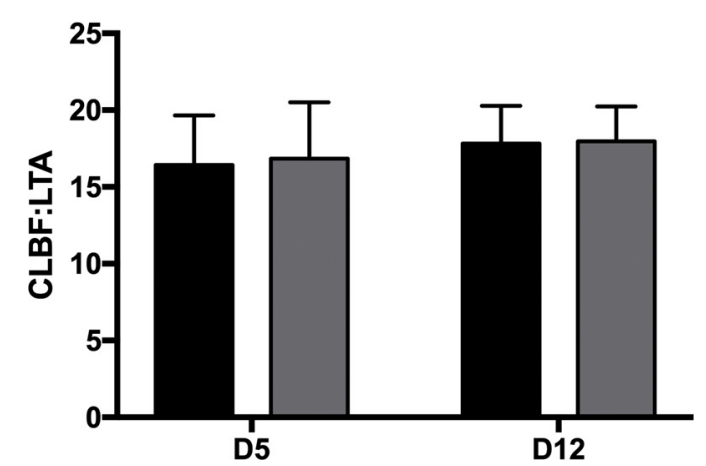

Fig. 4. (A) Corpus luteum blood flow (CLBF) and (B) adjusted CLBF, in which the CLBF was divided by luteal tissue area (LTA; CLBF:LTA ratio) 5 (D5) and 12 (D12) days after the time of ovulation for cows from the LPS and control group; The LPS group $(n=9)$ group were treated with an intrafollicular injection of lipopolysaccharide (LPS; $1 \mu \mathrm{g} / \mathrm{mL})$ and the control group $(n=9)$ was treated with an intrafollicular injection of saline solution $(\mathrm{NaCl} 0.9 \%) 12 \mathrm{~h}$ after withdrawal of an intravaginal progesterone device; Only six cows had ovulations in the LPS group, therefore CL measurements were conducted on six cows of this group; The CLBF and CLBF:LTA were evaluated using the Student's t test; Values of $P \leq 0.05$ were considered significant. 
groups. Values for blood flow variables CLBF (Fig. 4A) and CBFL:LTA ratio (Fig. 4B) were also not different between groups at D5 and D12 $(P>0.05$ ). Additionally, concentrations of P4 at D5 (control $4.8 \pm 0.7$ compared with LPS $4.7 \pm 0.9 \mathrm{ng} / \mathrm{mL} ; P=0.9$ ) and D12 (control $8.8 \pm 0.9$ compared with LPS $8.9 \pm 1.4 \mathrm{ng} / \mathrm{mL} ; P=0.9$ ) were not different between groups.

\section{Discussion}

In the present study, the treatment with LPS was used as a method to evaluate the direct effects of LPS on the dominant ovarian follicle during the final stages of dominant follicle growth, ovulation process and luteal development. To the best of our knowledge, there is no previous study evaluating the in vivo effects of LPS directly on ovarian follicles of cattle. The results of the present study indicate the treatment with LPS induced an increased follicular blood flow, a reduced rate of follicle growth, a delayed time to ovulation and a reduced percentage of cows having ovulations. The dose of LPS injected is consistent with concentrations in large follicles of cows that had been diagnosed with clinical endometritis (Herath et al., 2007) and during in vitro studies with granulosa cells in culture (Bromfield and Sheldon, 2011). In addition, it is important to emphasize that the procedure used for i.f. injection was adequate, as all cows in the control group had ovulations after injection of saline solution.

The LPS treatment induced an increased blood flow in the preovulatory follicle. This may be the result of the local inflammatory response because the acute inflammatory processes are characterized by vascular expansion and increased local blood flow, exudation of liquids, and increased flow of plasma proteins and migration of leukocytes and neutrophils into the inflamed tissues (Bhoola et al., 1992). The inflammatory response, therefore, would be expected after injection of LPS into the ovarian follicle. It is also important to note that no increase in body temperature was observed after i.f. injection of LPS, further indicating the inflammatory response only occurred in the follicle and not systemically. Results of previous studies indicate i.v. LPS treatments induce increases in body temperature after the treatments (Campos et al., 2017). In addition, the total amount of LPS injected i.f. was at maximum $2 \mu g$ in the current study, while in a previous study the average amount of LPS injected i.v. was approximately $1250 \mu \mathrm{g}$ per cow (Campos et al., 2017). It is also important to mention that the LPS used was not ultrapure and, therefore, may contain other bacterial components which may affect the response to this treatment. It, however, was the same LPS used in a previous study (Campos et al., 2017) in which LPS was administered i.v. It was beyond the scope of the current study, however, assessment of the LPS activity in the follicular fluid could provide significant insights with regard to its actions in future studies. As cows are exposed to bacterial contaminants constantly, even from the intravaginal progesterone devices during estrous synchronization, this could also affect the amount of endotoxins inside the follicle and further impair follicle growth. Even with these limitations, the results of the present study further indicate the actions of small amounts of LPS that are in preovulatory follicles and local effects of this substance.

Uterine diseases in cows induce an inflammatory processes, stimulating a systemic response that indirectly disrupts the endocrine function of the hypothalamic-hypophyseal-ovarian axis (Herath et al., 2006). This uterine bacterial contamination impairs follicle growth and E2 production, reducing the percentage of cows having ovulations (Sheldon et al., 2002). Furthermore, the LPS administered via an infusion in the uterine lumen of heifers induced a delayed pre-ovulatory LH release and ovulation (Peter et al., 1989) and the LPS administered during estrus delayed the timing of the preovulatory LH release and ovulation (Lavon et al., 2008). In the current study, a single i.f. injection of LPS was enough to decrease follicle growth and affect the time of ovulation. Results of the present study indicate that the systemic effects of LPS on LH secretion and ovulation may be mediated by ovarian produced E2 because there is LPS in the follicular fluid of cows with endometritis (Herath et al., 2007; Magata et al., 2014) and results of the present study indicate the local effects of LPS are lead to disruptions of follicle growth. In addition to having delayed times to ovulating, a smaller percentage of cows treated with LPS had ovulations in the present study. In previous studies, there was a smaller number of cows treated with LPS having ovulations (Williams et al., 2008) and postpartum cows that did not have ovulations had a greater concentration of LPS in the follicular fluid (Cheong et al., 2017). The presence of LPS in the follicular fluid, therefore, can be an important cause for the postpartum delay in resumption of estrous cyclic functions after parturition.

In the present study, cows treated with LPS had a lesser follicle growth rate and longer periods to the time of ovulation. The diameter of the follicle from which ovulation occurred was not different between the two groups. These results indicate, that although the diameter of the follicle from which ovulation occurred was similar, follicles from the LPS group had a longer interval of growth to the time the dominant follicle was of a diameter that is typical for ovulation of follicles. This, therefore, is the reason for the delay in the time when ovulation occurred in cows of the LPS-treated as compared with those in the control group. The immune capacity of granulosa cells and the responses to LPS may be an important mechanism related to infertility in cattle because the production of E2 by granulosa cells is essential during follicular development (Bromfield and Sheldon, 2011). Results of previous studies indicate intrafollicular accumulation of LPS can reduce E2 production (Magata et al., 2014). Cows with uterine infections have a lesser rate of follicular growth and lesser E2 concentrations (Sheldon et al., 2002; Williams et al., 2007). Similarly, an effect of treatment with LPS is a reduction in expression of steroidogenic genes in granulosa cells of the pre-ovulatory follicle in cows (Campos et al., 2017). Results of in vitro studies also indicate there is a lesser E2 production and steroidogenic enzyme expression in granulosa cells treated with LPS (Herath et al., 2007; Price et al., 2013). Collectively the data from these studies indicate effects of LPS are to reduce granulosa cell E2 synthesis, in follicle growth rate and delayed time to when ovulation occurs. Results from in vitro studies indicate LPS treatments during the period of oocyte maturation had effects subsequent to fertilization of the oocyte such as impaired nuclear maturation, reduction in cleavage rate and a delayed embryonic development (Soto et al., 2003; Magata and Shimizu, 2017; Zhao et al., 2017). Thus, it is possible that in addition to affecting the time of ovulation, the LPS may compromise oocyte viability, thus having a detrimental effect on the fertility of affected cows.

Follicular diameter is often associated with fertility in cows because when ovulations occur from smaller follicles there is development of smaller CL, and consequently less P4 production and a lesser capacity to support the physiologic functions that are 
conducive to maintenance of pregnancy (Vasconcelos et al., 2001). Results of a previous study indicate postpartum cows with uterine infections have a lesser growth rate of the first postpartum follicle, resulting in the ovulation from a smaller follicle (Williams et al., 2007). This resulted in development of a smaller CL and lesser plasma P4 concentrations (Williams et al., 2007). In the present study, however, the diameter of CL as well as the production of P4 was similar for cows treated with LPS and cows of the control group. Similarly, in the present study there was no difference in luteal tissue area and blood flow. This is probably due to the LPS from the treatment causing a delay in the time of ovulation among the cows having ovulations, however, the diameter of the follicle from which ovulation occurred was not different for LPS-treated cows and those of the control group. The CL developing after the ovulations were of similar diameter and P4 production. It, however, is important to emphasize that, in the present study, only one i.f. treatment was administered and it cannot be discounted that there could be a negative effect of LPS on CL function in cows when there is LPS present for longer periods to effect tissue functions.

In conclusion, the hypothesis in the present study that LPS has a direct effect on the dominant ovarian development and ovulation was confirmed. The LPS from the intrafollicular injection reduced follicular growth rate, causing a delay by approximately $28 \mathrm{~h}$ in the time when ovulation occurred, and a reduction in the number of cows having ovulations. Even though there was a suppressed rate of follicle development and delay in the time of ovulation occurrence, the diameter of the follicle at the time of ovulation was not affected, resulting in similar CL diameter and P4 production subsequent to ovulation.

\section{Declaration of Competing Interest}

The authors declare no conflicts of interest.

\section{Acknowledgements}

This study was supported by Fundação de Amparo à Pesquisa do Estado do RS (FAPERGS), Conselho Nacional de Desenvolvimento Científico e Tecnológico (CNPq), Coordenação de Aperfeiçoamento de Pessoal de Nível Superior - Brasil (CAPES, Finance Code 001) and EMBRAPA.

\section{References}

Battaglia, D.F., Krasa, H.B., Padmanabhan, V., Viguie, C., Karsch, F.J., 2000. Endocrine alterations that underlie endotoxin-induced disruption of the follicular phase in ewes. Biol. Reprod. 62, 45-53. https://doi.org/10.1095/biolreprod62.1.45.

Bauman, D.E., Currie, W.B., 1980. Partitioning of nutrients during pregnancy and lactation: a review of mechanisms involving homeostasis and homeorhesis. J. Dairy Sci. 63, 1514-1529. https://doi.org/10.3168/jds.S0022-0302(80)83111-0.

Bhoola, K.D., Figueroa, C.D., Worthy, K., 1992. Bioregulation of kinins: kallikreins, kininogens, and kininases. Pharmacol. Rev. 44, 1-80.

Bromfield, J.J., Sheldon, I.M., 2011. Lipopolysaccharide initiates inflammation in bovine granulosa cells via the TLR4 pathway and perturbs oocyte meiotic progression in vitro. Endocrinology 152, 5029-5040. https://doi.org/10.1210/en.2011-1124.

Bromfield, J.J., Sheldon, I.M., 2013. Lipopolysaccharide reduces the primordial follicle pool in the bovine ovarian cortex ex vivo and in the murine ovary in vivo. Biol. Reprod. 88, 1-9. https://doi.org/10.1095/biolreprod.112.106914.

Campos, F.T., Rincón, J.A.A., Acosta, D.A.V., Silveira, P.A.S., Pradieé, J., Correa, M.N., Gasperin, B.G., Pfeifer, L.F.M., Barros, C.C., Pegoraro, L.M.C., Schneider, A., 2017. The acute effect of intravenous lipopolysaccharide injection on serum and intrafollicular HDL components and gene expression in granulosa cells of the bovine dominant follicle. Theriogenology 89, 244-249. https://doi.org/10.1016/j.theriogenology.2016.11.013.

Carroll, J.A., Reuter, R.R., Chase Jr, C.C., Coleman, S.W., Riley, D.G., Spiers, D.E., Arthington, J.D., Galyean, M.L., 2009. Profile of the bovine acute-phase response following an intravenous bolus-dose lipopolysaccharide challenge. Innate Immun. 15, 81-89. https://doi.org/10.1177/1753425908099170.

Cheong, S.H., Sa Filho, O.G., Absalon-Medina, V.A., Schneider, A., Butler, W.R., Gilbert, R.O., 2017. Uterine and systemic inflammation influences ovarian follicular function in postpartum dairy cows. PLoS One 12, e0177356. https://doi.org/10.1371/journal.pone.0177356.

Drackley, J.K., Cardoso, F.C., 2014. Prepartum and postpartum nutritional management to optimize fertility in high-yielding dairy cows in confined TMR systems. Animal 8 (Suppl 1), 5-14. https://doi.org/10.1017/S1751731114000731.

Esposito, G., Irons, P.C., Webb, E.C., Chapwanya, A., 2014. Interactions between negative energy balance, metabolic diseases, uterine health and immune response in transition dairy cows. Anim. Reprod. Sci. 144, 60-71. https://doi.org/10.1016/j.anireprosci.2013.11.007.

Ferreira, R., Oliveira, J.F., Fernandes, R., Moraes, J.F., Goncalves, P.B., 2007. The role of angiotensin II in the early stages of bovine ovulation. Reproduction 134, 713-719. https://doi.org/10.1530/REP-07-0239.

Ginther, O.J., 2007. Follicle blood flow. Ultrasonic Imaging and Animal Reproduction: Color-Doppler Ultrasonography. Equiservises Publishing, Cross Plains, pp. 87-114.

Hakogi, E., Tamura, H., Tanaka, S., Kohata, A., Shimada, Y., Tabuchi, K., 1989. Endotoxin levels in milk and plasma of mastitis-affected cows measured with a chromogenic limulus test. Vet. Microbiol. 20, 267-274. https://doi.org/10.1016/0378-1135(89)90050-3.

Hammon, D.S., Evjen, I.M., Dhiman, T.R., Goff, J.P., Walters, J.L., 2006. Neutrophil function and energy status in Holstein cows with uterine health disorders. Vet. Immunol. Immunopathol. 113, 21-29. https://doi.org/10.1016/j.vetimm.2006.03.022.

Herath, S., Dobson, H., Bryant, C.E., Sheldon, I.M., 2006. Use of the cow as a large animal model of uterine infection and immunity. J. Reprod. Immunol. 69, 13-22. https://doi.org/10.1016/j.jri.2005.09.007.

Herath, S., Williams, E.J., Lilly, S.T., Gilbert, R.O., Dobson, H., Bryant, C.E., Sheldon, I.M., 2007. Ovarian follicular cells have innate immune capabilities that modulate their endocrine function. Reproduction 134, 683-693. https://doi.org/10.1530/REP-07-0229.

Lavon, Y., Leitner, G., Goshen, T., Braw-Tal, R., Jacoby, S., Wolfenson, D., 2008. Exposure to endotoxin during estrus alters the timing of ovulation and hormonal concentrations in cows. Theriogenology 70, 956-967. https://doi.org/10.1016/j.theriogenology.2008.05.058.

LeBlanc, S.J., Duffield, T.F., Leslie, K.E., Bateman, K.G., Keefe, G.P., Walton, J.S., Johnson, W.H., 2002. Defining and diagnosing postpartum clinical endometritis and its impact on reproductive performance in dairy cows. J. Dairy Sci. 85, 2223-2236. https://doi.org/10.3168/jds.S0022-0302(02)74302-6.

Lucy, M.C., 2008. Functional differences in the growth hormone and insulin-like growth factor axis in cattle and pigs: implications for post-partum nutrition and reproduction. Reprod. Domest. Anim. 43 (Suppl 2), 31-39. https://doi.org/10.1111/j.1439-0531.2008.01140.x.

Magata, F., Horiuchi, M., Echizenya, R., Miura, R., Chiba, S., Matsui, M., Miyamoto, A., Kobayashi, Y., Shimizu, T., 2014. Lipopolysaccharide in ovarian follicular fluid influences the steroid production in large follicles of dairy cows. Anim. Reprod. Sci. 144, 6-13. https://doi.org/10.1016/j.anireprosci.2013.11.005.

Magata, F., Ishida, Y., Miyamoto, A., Furuoka, H., Inokuma, H., Shimizu, T., 2015. Comparison of bacterial endotoxin lipopolysaccharide concentrations in the blood, ovarian follicular fluid and uterine fluid: a clinical case of bovine metritis. J. Vet. Med. Sci. 77, 81-84. https://doi.org/10.1292/jvms.14-0333.

Magata, F., Shimizu, T., 2017. Effect of lipopolysaccharide on developmental competence of oocytes. Reprod. Toxicol. 71, 1-7. https://doi.org/10.1016/j.reprotox. 
2017.04.001.

Martinez, M.F., Kastelic, J.P., Bo, G.A., Caccia, M., Mapletoft, R.J., 2005. Effects of oestradiol and some of its esters on gonadotrophin release and ovarian follicular dynamics in CIDR-treated beef cattle. Anim. Reprod. Sci. 86, 37-52. https://doi.org/10.1016/j.anireprosci.2004.06.005.

Mateus, L., Lopes da Costa, L., Diniz, P., Ziecik, A.J., 2003. Relationship between endotoxin and prostaglandin (PGE2 and PGFM) concentrations and ovarian function in dairy cows with puerperal endometritis. Anim. Reprod. Sci. 76, 143-154. https://doi.org/10.1016/S0378-4320(02)00248-8.

Moresco, E.M., LaVine, D., Beutler, B., 2011. Toll-like receptors. Curr. Biol. 21, R488-493. https://doi.org/10.1016/j.cub.2011.05.039.

Peter, A.T., Bosu, W.T., DeDecker, R.J., 1989. Suppression of preovulatory luteinizing hormone surges in heifers after intrauterine infusions of Escherichia coli endotoxin. Am. J. Vet. Res. 50, 368-373.

Piersanti, R.L., Horlock, A.D., Block, J., Santos, J.E.P., Sheldon, I.M., Bromfield, J.J., 2019. Persistent effects on bovine granulosa cell transcriptome after resolution of uterine disease. Reproduction. https://doi.org/10.1530/REP-19-0037.

Price, J.C., Bromfield, J.J., Sheldon, I.M., 2013. Pathogen-associated molecular patterns initiate inflammation and perturb the endocrine function of bovine granulosa cells from ovarian dominant follicles via TLR2 and TLR4 pathways. Endocrinology 154, 3377-3386. https://doi.org/10.1210/en.2013-1102.

Ribeiro, E.S., Gomes, G., Greco, L.F., Cerri, R.L.A., Vieira-Neto, A., Monteiro Jr, P.L.J., Lima, F.S., Bisinotto, R.S., Thatcher, W.W., Santos, J.E.P., 2016. Carryover effect of postpartum inflammatory diseases on developmental biology and fertility in lactating dairy cows. J. Dairy Sci. 99, 2201-2220. https://doi.org/10.3168/jds. 2015-10337.

Sheldon, I.M., Cronin, J., Goetze, L., Donofrio, G., Schuberth, H.J., 2009. Defining postpartum uterine disease and the mechanisms of infection and immunity in the female reproductive tract in cattle. Biol. Reprod. 81, 1025-1032. https://doi.org/10.1095/biolreprod.109.077370.

Sheldon, I.M., Dobson, H., 2004. Postpartum uterine health in cattle. Anim. Reprod. Sci. 82-83, 295-306. https://doi.org/10.1016/j.anireprosci.2004.04.006.

Sheldon, I.M., Noakes, D.E., Rycroft, A.N., Pfeiffer, D.U., Dobson, H., 2002. Influence of uterine bacterial contamination after parturition on ovarian dominant follicle selection and follicle growth and function in cattle. Reproduction 123, 837-845. https://doi.org/10.1530/rep.0.1230837.

Soto, P., Natzke, R.P., Hansen, P.J., 2003. Identification of possible mediators of embryonic mortality caused by mastitis: actions of lipopolysaccharide, prostaglandin F2alpha, and the nitric oxide generator, sodium nitroprusside dihydrate, on oocyte maturation and embryonic development in cattle. Am. J. Reprod. Immunol. 50, 263-272. https://doi.org/10.1034/j.1600-0897.2003.00085.x.

Suzuki, C., Yoshioka, K., Iwamura, S., Hirose, H., 2001. Endotoxin induces delayed ovulation following endocrine aberration during the proestrous phase in Holstein heifers. Domest. Anim. Endocrinol. 20, 267-278. https://doi.org/10.1016/S0739-7240(01)00098-4.

Vasconcelos, J.L., Sartori, R., Oliveira, H.N., Guenther, J.G., Wiltbank, M.C., 2001. Reduction in size of the ovulatory follicle reduces subsequent luteal size and pregnancy rate. Theriogenology 56, 307-314. https://doi.org/10.1016/s0093-691x(01)00565-9.

Williams, E.J., Fischer, D.P., Noakes, D.E., England, G.C., Rycroft, A., Dobson, H., Sheldon, I.M., 2007. The relationship between uterine pathogen growth density and ovarian function in the postpartum dairy cow. Theriogenology 68, 549-559. https://doi.org/10.1016/j.theriogenology.2007.04.056.

Williams, E.J., Sibley, K., Miller, A.N., Lane, E.A., Fishwick, J., Nash, D.M., Herath, S., England, G.C., Dobson, H., Sheldon, I.M., 2008. The effect of Escherichia coli lipopolysaccharide and tumour necrosis factor alpha on ovarian function. Am. J. Reprod. Immunol. 60, 462-473.

Zhao, S.J., Pang, Y.W., Zhao, X.M., Du, W.H., Hao, H.S., Zhu, H.B., 2017. Effects of lipopolysaccharide on maturation of bovine oocyte in vitro and its possible mechanisms. Oncotarget 8, 4656-4667. https://doi.org/10.18632/oncotarget.13965. 